\title{
The Public Library Research Programme in the Republic of Ireland
}

\author{
Annette Kelly
}

\section{Background}

The importance of research in libraries in Ireland across all sectors was highlighted in the report, Joining Forces: Delivering Libraries and Information Services in the Information Age (1999).

A survey of a range of practitioners within the LIS sector in Ireland about their research activities over the previous 3 years found that:

- $21 \%$ indicated that they had been involved in research;

- Of the respondents who stated they had not been involved with any research activity, $57 \%$ indicated that they would like to become involved in future research, $41 \%$ were uncertain, and $2 \%$ did not want to be involved.

The main reasons given for non-involvement were:

- Lack of staff time [69\%]

- Lack of funding [42\%]

- Lack of information on research opportunities [36\%]

- Lack of a suitable research proposal [29\%]

- Lack of staff [4\%]

Overall, $83 \%$ of those surveyed agreed that there is a need to encourage a culture of research in library and information services in Ireland. $6 \%$ disagreed with this statement.

In addressing the main reason, lack of staff time, Joining Forces identified a "serious lack of staff with research skills and project management experience without which the alternative would be the contracting out of research to consultants".

Joining Forces recommended that libraries should collaborate on research proposals, within and outside their own sectors and with other public and private agencies, nationally and internationally.

In 1998, the public library policy report Branching Out concluded that research into issues of relevance to public libraries in Ireland was inadequate and that the best use was not being made of the research that was available. It found that most of the research being undertaken by the Irish library / information sector tended to be applied or EU driven. While the report recognised the advantages that accrued to organisations and, perhaps more so, to staff involved with these EU projects, it 
queried the relevance of the research to the development and improvement of service provision locally.

Branching Out concluded that local authority library services generally supported the concept of research but encountered particular difficulties:

- in carrying out research that is of specific use to them in delivering services;

- in accessing relevant research carried out elsewhere;

- in disseminating the results of their research.

The report found:

- little evidence of services being developed on the basis of a sound research project; and

- little evidence of any supportive research being carried out during the compilation of statutory local development plans or of significant changes being made to activities or services consequent on research.

Branching Out recommended:

- the establishment of a co-ordinated approach to the development and funding of public library research;

- that the programme be designed by a representative group of public librarians and that its implementation be co-ordinated by the Library Council;

- that this co-ordination would also include the dissemination of relevant research to library authorities as well as the exploitation of research carried out by them;

- that a public library research fund be established; and

- the commissioning of research from third parties.

\section{The Public Library Research Programme}

The Public Library Research Programme was established in 2002 to implement the recommendations of Branching Out for a formalised research programme which would be focused on the provision of new, innovative and improved library services.

Simple extensions to new services, or some new infrastructure, would not be eligible for funding. Projects would have to be groundbreaking, either by delivering new services, addressing new audiences, or pioneering new initiatives with different partners.

The Public Library Research Programme is managed by the Public Library Research Committee, and administered by An Chomhairle Leabharlanna/ The Library Council and includes members from the Department of the Environment, Heritage and Local Government, the Library Association of Ireland, the School of Information and Library Studies (National University of Ireland, Dublin), and An Chomhairle Leabharlanna. 
There have been four calls for proposals so far and six projects are either underway or completed.

\section{PLRP Calls for proposals}

Between 2002 and 2008 there have been four calls for proposals under the Public Library Research Programme:

$>$ Call 2002: 13 proposals submitted by 12 library authorities - one proposal selected (Donegal County); one project funded (Taobh Tire);

$>$ Call 2003: nine proposals submitted by eight library authorities - five successful proposers (from four library authorities); three projects funded (Libraries \& Cultural Diversity, Marketing and eGovernment);

$>$ Call 2005: seven proposals submitted by seven library authorities, none selected;

$>$ Call 2007: three proposals submitted - three projects underway or under consideration.

\section{Topics covered by the calls}

Topics for the Calls for proposals in 2002 and 2003 were:

- Improving delivery of services;

- Marketing of public libraries;

- Partnership with third parties;

- Libraries and eGovernment.

In the first call, the lists of suggested topics were not prescriptive and proposals on any other relevant and related issues were welcomed.

In 2005, expressions of interest on possible topics for a call were requested and received from seven library authorities. The committee considered the proposed topics in detail and agreed that many of the most relevant topics in terms of service development fell into three categories:

- Reader development;

- Life long learning;

- Social inclusion.

It was agreed that these categories would be the topics for the 2005 call and proposals which address issues which were not included in these categories were not deemed eligible for funding.

Topics for the 2007 call were based on issues highlighted in the review of the Branching Out programme as requiring further development:

- Membership and issues;

- Opening hours;

- School libraries. 


\subsection{Evaluation criteria}

The Committee sought the advice of independent evaluators in selecting projects for each call. The experts evaluated the proposals against three criteria, similar to the EU Framework model:

- Quality and innovation: The quality of the research proposed and its contribution to addressing the key action lines detailed in the call; the originality, degree of innovation in the proposal;

- Contribution to public library policy and service development: Compliance of the project to broad national policy objectives as outlined in Branching Out; the extent to which the project would contribute to solving problems at the local and national level; the extent to which the expected results would have a measurable and replicable impact; the project's contribution to end user service development. Each project should seek to develop services that are additional to the standard provision and development of public library services;

- Resource, partnership and management: the quality of the management and project approach proposed, in particular the appropriateness, clarity, consistency, efficiency and completeness of the proposed tasks, the scheduling arrangements (with milestones) and the management structure. In addition, the tools to be used for monitoring project progress, including the quality of specified indicators of impact and performance, and ensuring good communication within the project consortium; the quality of the partnership and involvement of users and/or other actors in the field when appropriate; in particular, the research competence and expertise and the roles and functions within the consortium and the complementarities of the partners; the appropriateness of the resources - the manpower effort for each partner and task, the quality and/or level and/or type of manpower allocated, durables, consumables, travel and any other resources to be used. In addition, the resources not reflected in the budget (e.g. facilities to carry out the research and the expertise of key personnel).

In the first Call (2002), proposals failed especially under resources, partnership and management. They complied with public library policies but lacked quality and innovation.

In the 2003 Call, failed proposals showed similar patterns. It is interesting to notice that seven of the 13 authorities which attended the workshop organised for this Call have never submitted a proposal under the programme. On the other hand, five authorities attending the workshop submitted a proposal in the 2003 Call and four of them were successful.

The more common problems with the proposals in the 2005 Call were as follows:

- Insufficient research content;

- Inadequate project planning and/or partnership building; 
- Requests for excessive funding or funding for work which falls within the day-to-day remit of the library services.

\section{PLRP projects}

Six projects have been funded under the Public Library Research Programme: Taobh Tíre, Libraries \& Cultural Diversity, Marketing, eGovernment, Community Partnerships and School Libraries. Two projects are outlined below.

\subsection{Taobh Tíre}

Taobh Tíre - a better library service for rural and isolated communities, was the first project to be approved for funding. Managed by Donegal County Council, with support provided by An Chomhairle Leabharlanna, Taobh Tíre is a research and action pilot project, which investigated and implemented new and innovative methods to deliver library services to remote and isolated areas in Donegal and established a model which could be replicated elsewhere.

Taobh Tíre has established a network of service points delivering library services to isolated communities across Donegal. A service point consists of a small collection of books (a taster collection), access to the online catalogue and the Internet, weekly delivery of requested books and a range of additional library services such as online reference and business information, interlibrary loan, etc. Each point is staffed by personnel trained by County Library staff, and is open for between twenty to sixty hours per week. Taobh Tíre has established fourteen new library service points in Donegal, including on offshore islands and in urban locations in Letterkenny. New service points are established in partnership with the local community, most commonly in the form of community development associations and co-operatives.

The interim report of the project was published in March 2005. The final report is due to be published in 2008 and will include key findings and recommendations for developing the service across Ireland. Full details on this initiative are available at www.donegallibrary.ie.

\subsection{Libraries \& Cultural Diversity}

This research project was selected following the second call in 2003 under the Public Library Research Programme. It investigated how Irish public libraries can develop better library services to the current multicultural and multilingual society in Ireland.

Project partners were Dublin City Council Public Libraries, Waterford City Libraries and Meath County Libraries. The project examined the national and international situation and carried out in depth investigations into comparative library services in the UK and Denmark. The research team compared public library stock acquisition and service delivery policies and practices in relation to culturally diverse users, both nationally and internationally. The library needs of selected foreign national communities living in Ireland were also investigated. 
Based on the results of this research, several pilot services were initiated to meet the expressed needs of survey respondents. The pilot services, together with existing relevant library services, were monitored and evaluated over the two year period 2004-2006. The results of these evaluations served as a basis for the final recommendations.

The final report, Meeting the challenges of cultural diversity: a report on the role of public libraries in Ireland was published in 2007 and is available at http://www.librarycouncil.ie/publications/documents/MulticulturereportFinalpdfA K.pdf .

Review of the PLRP

The PLRP Committee undertook a review of the programme in 2006 following an unsuccessful call. The review included an independent survey of library authorities.

\subsection{Programme Review}

Having operated the PLRP for four years the committee decided to review the programme. An independent company, Insight, carried out the review and reported in spring 2006. The review found that library managers view research as being very important but believed that there isn't a culture of research within library authorities. Due to resource limitations, many see research as a luxury. The principal barrier to participation in research was identified as lack of staff, followed by lack of staff skills and difficulty in replacing staff that are assigned to research projects.

Those who have previously been involved in research projects found the whole process beneficial from both a knowledge gained and staff learning perspective. It was also found that participation in research projects and implementation of research results has benefited the library service.

Local authority management also viewed research as being very important. They identified the benefits of research as contributing to more informed decisions and planning for future service needs.

\subsection{Review Conclusions}

The review recommended:

- Call topics and guidelines should be clear;

- Calls should be announced in the first quarter of the year and there should be a three month submission period;

- Information days should be provided at each stage of the process;

- There should be a pre submission phase where proposal outlines can be submitted and evaluated;

- A helpline and monitoring service should be made available; 
- Due to difficulties in staff release, replacement and up skilling, library authorities should be encouraged to engage external research expertise;

- Library authorities should be encouraged to involve staff at all stages of projects and project proposal;

- Project management and research skills training should be provided;

- The negotiation phase should provide for team building where authorities select to work together on a project;

○ Project planning, work plan and budget preparation should be provided.

- The PLRP team should liaise with library authorities at all stages of the process.

\section{Call for proposals 2007}

The Committee incorporated the recommendations of the review into the procedures for the Call for Proposals in 2007. The call for proposals for 2007 was issued in February with initial outline proposals to be submitted by mid March. A briefing day was held. The outline proposals were circulated to the committee and the feedback and recommendations were sent to each authority. The final closing date of the end of May was extended at the request of proposers. Three final proposals were received and were sent to the external reviewers.

There were no proposals addressing opening hours, Dublin City Libraries submitted a proposal under schools library service and Galway and Meath County Libraries addressed membership and usage.

An initial two day research training programme was provided. This will be followed up with specific training as requested by participants.

\section{Branching Out - Future Directions}

The policy report, Branching Out - Future Directions (2008), reviewed the development of the public library service under Branching Out and made recommendations for the next five years. It notes the implementation of the recommendations to establish a funded research programme and that a significant body of research had been undertaken, but sees the need to ensure the mainstreaming and implementation of the research findings. It envisages that the challenge for the next five years will be to develop further the culture of research in relation to the public library service by

- Developing a research framework including examples of possible research projects;

- Developing a database on library research projects; and

- Ensuring the continuation of funding.

The report recommends the continuation of the Public Library Research Programme (at a level to be agreed) and with stronger emphasis on dissemination and implementation of research findings. 


\section{Conclusions}

The Public Library Research Programme has been a learning experience for all concerned. The programme was set up to improve public library services and to encourage library authorities to propose and carry out the research themselves, either through their own staff or with the help of external consultants. It was envisaged that this would lead to the development of a research culture in Irish public libraries. To some extent, this objective is being achieved and can be seen in a range of planning and development initiatives underway in many authorities.

It would be incorrect to suggest that this is totally due to the Public Library Research Programme. Some authorities have their own research departments, either in the library service or in the parent service and they carry out their own research programmes. The public library service also operates within and interacts with the broader policy and research framework at national level, particularly in the areas of social and cultural development. There is also the interaction with libraries in other sectors, particularly academic libraries, which have issues of common concern for research purposes and this would be an area to be developed in the future.

In the past ten years, all authorities have benefited from increased staffing, increased education and training opportunities, improved infrastructure and funding which has raised the level at which services operate and this is reflected in the level of interest in research topics. Public library staff continue to be primarily occupied with delivering the service and this continues to be a barrier to participation in large scale research projects.

The projects which have worked best are those projects which address a local question and this reflects the local nature of the public library service in Ireland. Despite this, in a small country, the variations in service delivery are outweighed by the underlying similarities and most of the research topics can meet the requirement to deliver results that are replicable and inform the national picture. 


\section{References}

Branching out: a new public library service (1998) Dublin: Stationery Office. http://www.librarycouncil.ie/publications/documents/BranchingOut_report.pdf [accessed 06.12.08].

Branching out: future directions (2008) Dublin: Stationery Office. URL:

http://www.librarycouncil.ie/publications/documents/BranchingOut_FutureDirecti ons.pdf [accessed 06.12.08].

Joining forces: delivering libraries and information services in the information age, Executive Summary (1999) Dublin: An Chomhairle Leabharlanna. URL: http://www.librarycouncil.ie/publications/pdf/JoiningForcesExecutiveSummary.p df [accessed 06.12.08].

Meeting the challenges of cultural diversity: a report on the role of public libraries in Ireland (2007) Dublin: An Chomhairle Leabharlanna. URL:

http://www.librarycouncil.ie/publications/documents/MulticulturereportFinalpdfA $\underline{\text { K.pdf }}$ [accessed 06.12.08].

Taobh Tíre: a better library service for rural areas. Interim project report (2005) Dublin: An Chomhairle Leabharlanna. URL:

http://www.librarycouncil.ie/publications/pdf/Taobh_Tire_report.pdf [accessed 06.12.08]. 